\title{
Chemical Adsorption of Nitrogen Dioxide with an Activated Carbon Adsorption System
}

\author{
Mei-Ling Fang ${ }^{1}$, Ming-Shean Chou ${ }^{1}$, Cheng-Yu Chang ${ }^{1}$, Hsiao-Yu Chang ${ }^{1 *}$, Chih-Hsiang \\ Chen $^{2,3}$, Sheng-Lun Lin ${ }^{4,5,6^{*}}$, Yen-Kung Hsieh
}

${ }^{1}$ Institute of Environmental Engineering, National Sun Yat-sen University, Kaohsiung 80424, Taiwan

${ }^{2}$ Department of Finance, Ming Chuan University, Taipei 11103, Taiwan

${ }^{3}$ School of Software and Microelectronics, Peking University, Beijing 102600, China

${ }^{4}$ Department of Civil Engineering and Geomatics, Cheng Shiu University, Kaohsiung 83347, Taiwan

${ }^{5}$ Center for Environmental Toxin and Emerging-Contaminant Research, Cheng Shiu University, Kaohsiung 83347, Taiwan

${ }^{6}$ Super Micro Mass Research and Technology Center, Cheng Shiu University, Kaohsiung 83347, Taiwan

${ }^{7}$ Ocean Affairs Council, Kaohsiung 80661, Taiwan

\begin{abstract}
Nitrogen dioxide $\left(\mathrm{NO}_{2}\right)$ is a pollutant that directly harm the human respiratory system, lead to inflammation, as well as to form the secondary aerosol pollutants. The main $\mathrm{NO}_{2}$ sources, combustion or thermal processes, were well controlled. However, the metal etching operation in semiconductor industry emits flue gases with reddish-brown $\mathrm{NO}_{2}$ fume that leads to visibility reduction, acidic odor, as well as negative effects on human health. In this study, a stream of flue gases with low $\mathrm{NO}_{2}(230 \pm 10 \mathrm{ppm})$ and $\mathrm{NO}(50 \mathrm{ppm})$ concentrations were conducted to pass through an activated carbon-packed fixed bed for analyzing the adsorptive conversion behavior of $\mathrm{NO}_{2}$ by the activated carbon (AC) at room temperature. The repeated adsorption test was carried out by washing the regenerated waste carbon with a caustic solution and water and drying. Results propose that at the beginning of adsorption, nitrogen dioxide combined with carbon to form $\mathrm{NO}$ and desorbed from carbon surface. The net adsorptive conversion removal capacity of $\mathrm{NO}_{2}$ by the virgin $\mathrm{AC}$ and regenerated $\mathrm{AC}$ was 224 and $155 \mathrm{mg} \mathrm{g}^{-1} \mathrm{AC}$, respectively. Regeneration restored around 70-75\% of effective surface area, pore volume, and adsorptive conversion capacity of the virgin AC. Leached caustic solution obtained from the carbon regeneration contained only nitrate and the phenomena indicates the adsorbed $-\mathrm{C}_{2}\left(\mathrm{ONO}_{2}\right)$ hydrolyzed following the Eq. (2) $-\mathrm{C}_{2}\left(\mathrm{ONO}_{2}\right)+\mathrm{H}_{2} \mathrm{O} \rightarrow 3-\mathrm{C}^{*}+-\mathrm{C}(\mathrm{O})$ $+2 \mathrm{HNO}_{3}$, where $-\mathrm{C}^{*}$ denotes active site on the carbon surface.
\end{abstract}

Keywords: Activated carbon; Nitrogen dioxide; Adsorption; Air pollution control.

\section{INTRODUCTION}

Nitrogen dioxide is an important pollutant in the air index. The exhaust gas generated by the metal etching operation in the TFT process has a reddish-brown color (yellow when diluted). The $\mathrm{NO}_{2}$ smoke has photochemical reactivity, which may cause acidic odor, cardiovascular effects, lung cancer, and negative health effects. (Wu and Chou, 2014; Du et al., 2017; Fang et al., 2017; Jiang et al., 2017; Xu et al.,

\footnotetext{
* Corresponding author.

Tel.: 88677358800 ext. 2605

E-mail address: cbmsgml@gmail.com

** Corresponding author.

Tel.: 88675254428

E-mail address: d9033803@student.nsysu.edu.tw
}

2017; Zhang et al., 2017; Wang et al., 2018).

Techniques most commonly used to eliminate $\mathrm{NO}_{2}$ gas include selective non-catalytic reduction (SNCR), chemical scrubbing, and selective catalytic reduction (SCR). SCR and SNCR operate at gas temperatures in the range of 270 $400^{\circ} \mathrm{C}$ and $900-1000^{\circ} \mathrm{C}$, respectively, indicating they would be both better operated under high-temperature flue gas condition (Shen and Rochelle, 1998; Chen et al., 2002; Curtin, 2005; Gao et al., 2009; Chen et al., 2011; Gao et al., 2011; Gao et al., 2012; Wu and Chou, 2014; Huang et al., 2017; Liu et al., 2017; Chen et al., 2018). The most suitable method for removing $\mathrm{NO}_{2}$ and mixed acids, e.g., nitric and phosphoric, is wet scrubbing with sodium sulfide and caustic soda by the following equation: $8 \mathrm{NO}_{2}+\mathrm{NaSH}+$ $9 \mathrm{NaOH} \rightarrow 8 \mathrm{NaNO}_{2}+\mathrm{Na}_{2} \mathrm{SO}_{4}+5 \mathrm{H}_{2} \mathrm{O}$. They are commonly used in an aluminum etching processes for producing thin film transistors-liquid crystal displayers. Unfortunately, the odor of hydrogen sulfide would further be emitted from the

\section{Change history:}


effluent of the scrubber and become a secondary pollution (Wu and Chou, 2014).

Gao et al. (2011) reported reactive adsorption of NO to $\mathrm{NO}_{2}$ at $50^{\circ} \mathrm{C}$. It was then observed that $\mathrm{NO}_{2}$ was adsorbed and reduced to $\mathrm{NO}$, when the $\mathrm{AC}$ was exposed to $\mathrm{NO}_{2}$. The study showed that no net removal of $\mathrm{NO}_{\mathrm{x}}\left(\mathrm{NO}\right.$ and $\left.\mathrm{NO}_{2}\right)$ was observed when $\mathrm{NO}_{2}$ was adsorbed and $\mathrm{NO}$ desorbed at $50^{\circ} \mathrm{C}$. However, this study indicates that $\mathrm{AC}$ micropores form a decomposition reaction site that is released together with -C(ONO 2$)-\mathrm{C}-\mathrm{NO}$ and NO. (Gao et al., 2011).

The processes of $\mathrm{NO}_{2}$ adsorption-reduction on pitch-based $\mathrm{ACF}$ (activated carbon fiber) was reported with the controlled conditions of $\mathrm{NO}_{2}(250-1000 \mathrm{ppm})$ and $\mathrm{O}_{2}(0-10 \%)$ in the tested gaseous mixture at $30-70^{\circ} \mathrm{C}$ (Shirahama et al., 2002). ACFs shows rapid $\mathrm{NO}_{2}$ conversion and reduction at $30^{\circ} \mathrm{C}$, while the NO was continuously and steadily produced before the approaching of $\mathrm{NO}_{2}$ adsorption limit. The higher reaction temperature $\left(70^{\circ} \mathrm{C}\right)$ was found to decrease the adsorption rate in a steady-state test and shorten the operation period before the breakthrough of $\mathrm{NO}_{2}$. In addition to this, $\mathrm{NO}_{\mathrm{x}}$ adsorbed on ACF were oxidized from $\mathrm{NO}_{2}$ to $\mathrm{NO}_{3}$. This result points out that there are two pathways of $\mathrm{NO}_{2}$ adsorptions. One of them weakly adsorbs $\mathrm{NO}_{2}$ and terminate the adsorption and reduction when the active sites were saturated. The adsorbed $\mathrm{NO}_{3}$ generates $\mathrm{NO}_{2}$ and $\mathrm{NO}$, following the reactions of $-\mathrm{C}\left(\mathrm{ONO}_{2}\right) \rightarrow-\mathrm{C}-\left(\mathrm{NO}_{2}\right)+-\mathrm{CO}$ and $-\mathrm{C}\left(\mathrm{ONO}_{2}\right) \rightarrow-\mathrm{C}-\mathrm{NO}$ $+-\mathrm{CO}_{2}$ under heating process. The other strongly adsorption mechanism were approached by the reaction as $2-\mathrm{C}-\mathrm{NO}_{2} \rightarrow$ $-\mathrm{C}-\mathrm{NO}+-\mathrm{C}\left(\mathrm{ONO}_{2}\right)$. The adsorbed $\mathrm{NO}$ (-C-NO) was decomposed and released from the carbon surface and leaves $\mathrm{NO}_{3}$ bound with the surface of AC. One or two oxygen atom(s) were leaved on the AC surface and simultaneously evolve as $\mathrm{CO}$ and $\mathrm{CO}_{2}$, which further recovered the ability of $\mathrm{NO}_{2}$ adsorption (Shirahama et al., 2002).

Additionally, Zhang et al. (2008) indicated that the estimated $\mathrm{NO}_{2}$ adsorption capacity of activated carbon was about $70 \mathrm{~g} \mathrm{~kg}^{-1}$ at $25^{\circ} \mathrm{C}$, before it released $\mathrm{NO}_{2}$ from saturated carbon bed. There was no NO emission during the first 30minute operation. Depending on the surface conditions, some of $\mathrm{NO}$ formed by the $\mathrm{NO}_{2}$ conversion was adsorbed on the activated carbon surface, when the other was released into the exhaust gas. During thermal desorption, $\mathrm{O}_{2}, \mathrm{NO}$ and a small amount of $\mathrm{CO}$ and $\mathrm{CO}_{2}$ were released at the temperatures $<150^{\circ} \mathrm{C}$. (Zhang et al., 2008).

In some small metal etching processes, a limited flow of exhaust gas emitted only $\mathrm{NO}_{2}$. activated carbon can be used to convert $\mathrm{NO}_{2}$ to $\mathrm{NO}$, eliminating the color issues before emission. AC can also be used to purify indoor ambient air to protect people from long-term exposure with low $\mathrm{NO}_{2}$ concentrations. The US. EPA list $0.053 \mathrm{ppm}$ as the average 24-hour limit for $\mathrm{NO}_{2}$ in outdoor air (U.S. Environmental Protection Agency, 1987). The full or partially saturated AC could be regenerated by a caustic solution washing process. The processes may be simple in term of their treatment system and operation steps; however, their performance and economical information are still limited. Görgülü et al. (2018) stated that the nitrogen dioxide concentration existing in the environment can be harmful, in particular for asthmatics and it also has the potential to bring about other serious diseases. They observed the nitrogen dioxide adsorption on the active carbon for varying air temperatures, gas concentrations and air relative humidity. They have used parameters between $1 \mathrm{ppm}$ and $30 \mathrm{ppm}$ (for $\mathrm{NO}_{2}$ concentration), $23^{\circ} \mathrm{C}$ and $33^{\circ} \mathrm{C}$ (for air temperature), $30 \%$ and $90 \%$ (for air relative humidity). Results show that the humidity has not a remarkable effect on the adsorption of $\mathrm{NO}$; however, increasing relative humidity causes to a decrease in the capacity of the activated carbon for NO adsorption.

The current research focuses on the performance of an activated carbon bed for $\mathrm{NO}_{2}$ adsorption and the regeneration technique of saturated carbon with a caustic solution. The washed solution was analyzed to ascertain if the adsorbed $\mathrm{NO}_{2}$ was converted to nitrite and/or nitrate ions.

\section{METHODS AND MATERIALS}

The experimental setup consisted of a column packed with granular activated carbon (AC) and a $\mathrm{NO}_{\mathrm{x}}$-containing gas preparation and delivery system, as demonstrated in Fig. 1. The AC-packed column had an inner diameter of $1.0 \mathrm{~cm}$ and packed with crushed and screened AC for adsorption tests. The tested virgin activated carbon (ACRO-460) was supplied by ACRO Chemical Co., Taiwan. Table 1 shows the specifics some of the characteristics of the original AC received. The $\mathrm{AC}$ was crushed, ground and screened to get a sample of fine grains with sizes in $0.84-1.00 \mathrm{~mm}$. Before packing, the AC sample was conditioned in a desiccator for around 24 hours at $25 \pm 2^{\circ} \mathrm{C}$ to get an equilibrium moisture content of about $5 \%$. The sample was then weighted and packed into the column to a definite height for the adsorption test.

The operation conditions for adsorption tests were designed as shown in Table 2. During the first test, the effluent gas samples were analyzed half an hour for $\mathrm{NO}$ and $\mathrm{NO}_{2}$. The AC were eventually saturated by $\mathrm{NO}_{2}$, while the $\mathrm{NO}_{2}$ level in the effluent gas remained equal to the inlet port. After the saturation of $\mathrm{NO}_{2}$, the $\mathrm{AC}$ was immersed in $200 \mathrm{~mL}$ of an alkaline aqueous solution adjusted to $\mathrm{pH} 10$ using $\mathrm{NaOH}$ and stirred for 14 hours to leach the adsorbed nitrate and/or nitrite. The leached AC was then filtered by a suction pump and the filtrate stored for chemical analysis. The AC was then soaked in $200 \mathrm{~mL}$ pure water and stirred for 2 hours to leach out the residual nitrite and/or nitrate. The $2^{\text {nd }}$-leached $\mathrm{AC}$ (the regenerated $\mathrm{AC}$ ) was again filtered and the filtrate stored for chemical analysis. The regenerated AC was conditioned in the desiccator for 24 hours before being packed into the column. Because some $\mathrm{AC}$ was taken for analysis, mass of the $\mathrm{AC}$ for the $2^{\text {nd }}$ adsorption test was less than the previous one (Table 2 ). The $2^{\text {nd }}$ adsorption test lasted for 630 minutes. The virgin, exhausted virgin, regenerated, and exhausted regenerated carbon were analyzed for their surface properties, pore volume, and adsorbed oxygen contents.

A flue gas analyzer (Testo-340, Testo/Germany) was employed to determine the concentrations of $\mathrm{NO}$ and $\mathrm{NO}_{2}$ in gas samples. The analyzer has an accuracy of $\pm 5 \%$, according to the specifications supplied by the manufacturer. An ion chromatography (ICS-900, Dionex/USA) was utilized to quantify the levels of nitrite and nitrate in the filtrates obtained from the first regeneration and washing eluent. 


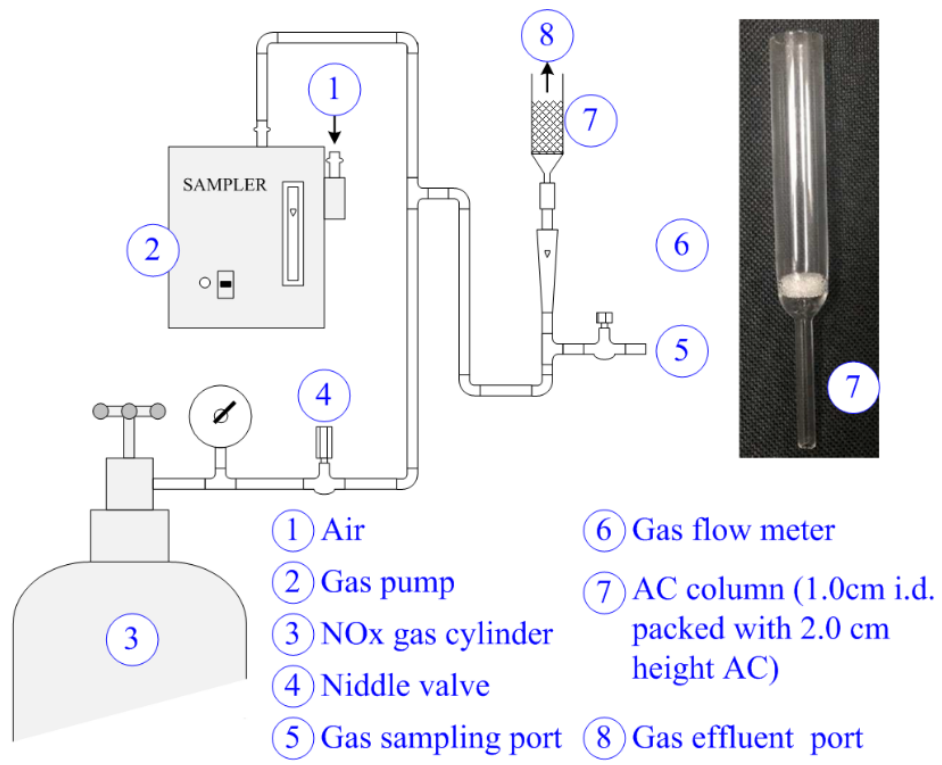

Fig. 1. Schematics of the experimental system.

Table 1. Some characteristics of the experimental AC as received.

\begin{tabular}{ll}
\hline Items & Characteristics \\
\hline Appearance & Cylindrical \\
Bulk density & $0.4-0.5 \mathrm{~g} \mathrm{~mL}^{-1}$ \\
Moisture & $<5 \%$ \\
Iodine value & $850 \mathrm{mg} \mathrm{g}^{-1}$ \\
\hline
\end{tabular}

Table 2. Influent gas to the AC column and the operating conditions.

\begin{tabular}{lll}
\hline Item & Parameters \\
\hline Influent gas & $\mathrm{NO}_{2}$ & $230 \pm 10 \mathrm{ppm}$ \\
& $\mathrm{NO}$ & $50 \mathrm{ppm}$ \\
& $\mathrm{NO}_{\mathrm{x}}\left(\mathrm{NO}_{2}+\mathrm{NO}\right)$ & $280 \pm 10 \mathrm{ppm}$ \\
& $0.6 \mathrm{~L} \mathrm{~min}^{-1}$ & $25^{\circ} \mathrm{C}$ \\
Influent gas flow rate & $1.00 \mathrm{~cm}$ \\
Operating temperature & $0.127 \mathrm{~m} \mathrm{~s}^{-1} @ 25^{\circ} \mathrm{C}$ \\
Inner diameter of AC column & $2.00 \mathrm{~cm} / 0.75 \mathrm{~g}$ \\
Superficial velocity for the gas flowing through the column cross-sectional area & $1.70 \mathrm{~cm} / 0.69 \mathrm{~g}$ \\
Packed height and mass of virgin AC & \\
Packed height and mass of regenerated AC & \\
\hline
\end{tabular}

The $\mathrm{pH}$ of the filtrates was measured by a $\mathrm{pH}$ meter $(\mathrm{pH} 526$, WTW/Germany). The instrument used to analyze the surface area and pore volume of the AC sample was a BET surface analyzer (ASAP 2020 Accelerated Surface Area and Porosimetry System, Micromeritics Instrument Co., USA).

\section{RESULTS AND DISCUSSION}

\section{$\mathrm{NO}_{2}$ Adsorptive Removal Breakthrough Curves}

Fig. 2(A) shows $\mathrm{NO}, \mathrm{NO}_{2}$ and $\mathrm{NO}_{\mathrm{x}}\left(\mathrm{NO}+\mathrm{NO}_{2}\right)$ concentrations of the gas influent to and effluent from the bed packed with the virgin $\mathrm{AC}$ as a function of time. During the initial $210 \mathrm{~min}$, there was less than $10 \mathrm{ppm} \mathrm{NO} \mathrm{N}_{2}$ emitted from the bed, indicating the removal efficiency of $\mathrm{NO}_{2}$ approached over $90 \%$ (as shown in Fig. 3). However, the effluent gas contained $102-196 \mathrm{ppm}$ in addition to the influent
$50 \mathrm{ppm}$ of $\mathrm{NO}$ and the additional $\mathrm{NO}$ was converted from $\mathrm{NO}_{2}$. NO increased rapidly in the first $30 \mathrm{~min}$, reached a maximum of $246 \mathrm{ppm}$ at $180 \mathrm{~min}$ and dominated the $\mathrm{NO}_{\mathrm{x}}$ emission before 280 min operation. Additionally, the $\mathrm{NO}_{\mathrm{x}}$ in the influent was predominated by $\mathrm{NO}_{2}$ after 360 -min operation, since the capability of $\mathrm{NO}_{2}$ adsorption of $\mathrm{AC}$ reduced. $\mathrm{An}$ approach of the influent $\mathrm{NO}_{\mathrm{x}}$ of $280 \mathrm{ppm}$ and effluent $\mathrm{NO}_{\mathrm{x}}$ of $286 \mathrm{ppm}$ at $600 \mathrm{~min}$ indicates that after the time, the carbon had been nearly saturated with $\mathrm{NO}_{2}$ and the conversion capability of $\mathrm{NO}_{2}$ to $\mathrm{NO}$ of the carbon was nearly diminished. The effluent gas had a $\mathrm{NO}_{\mathrm{x}}$ of $282 \mathrm{ppm}$ at the end $(720 \mathrm{~min})$ of the adsorption operation. Our finding of $\mathrm{NO}_{2} / \mathrm{NO}$ adsorption/ desorption phenomenon is similar to those observed in the study on $\mathrm{AC}$ treatment at $50^{\circ} \mathrm{C}$ for $\mathrm{NO}_{2}$, presented by Gao et al. (2011). The mechanism has been reported as follows Eqs. (1)-(6) and Fig. 4 (Gao et al., 2011): 

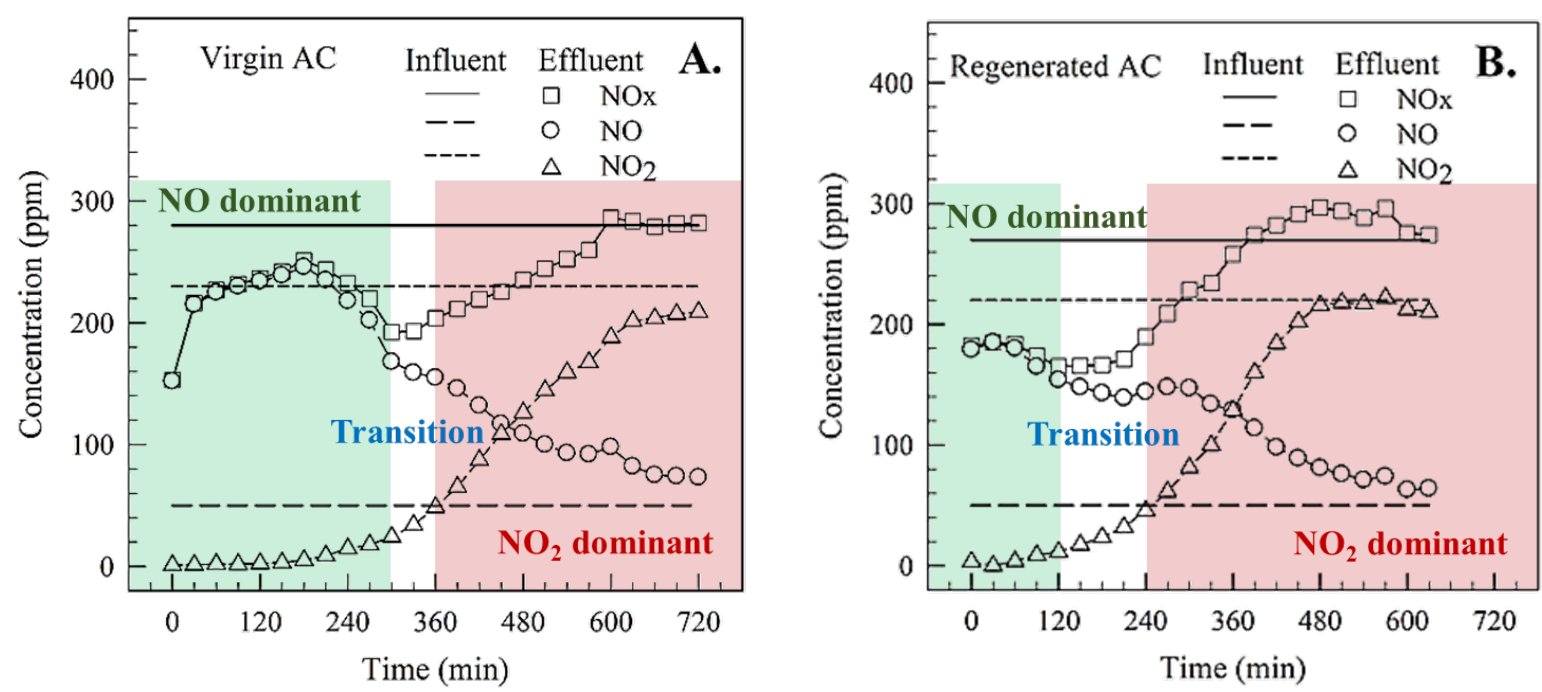

Fig. 2. Time variations of influent and effluent $\mathrm{NO}_{\mathrm{x}}\left(\mathrm{NO}+\mathrm{NO}_{2}\right), \mathrm{NO}$, and $\mathrm{NO}_{2}$ concentrations to and from the $(\mathrm{A})$ virgin $\mathrm{AC}$ and (B) regenerated AC columns.

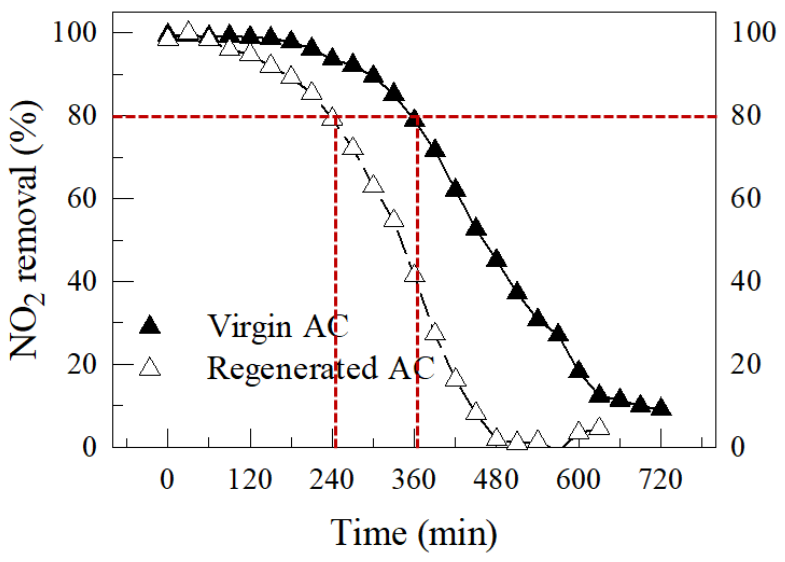

Fig. 3. Time variations of $\mathrm{NO}_{2}$ removal by the $\mathrm{AC}$.

$\mathrm{NO}_{2}+-\mathrm{C}^{*} \rightarrow-\mathrm{C}\left(\mathrm{NO}_{2}\right)$ or $\mathrm{NO}_{2}+-\mathrm{C}^{*} \rightarrow-\mathrm{C}(\mathrm{ONO})$

$-\mathrm{C}\left(\mathrm{NO}_{2}\right) \rightarrow-\mathrm{C}(\mathrm{O})+\mathrm{NO}$

$-2 \mathrm{C}(\mathrm{O})+2 \mathrm{NO}_{2} \rightarrow-2 \mathrm{C}\left(\mathrm{ONO}_{2}\right)$

$-2 \mathrm{C}\left(\mathrm{ONO}_{2}\right)+2 \mathrm{NO}_{2} \rightarrow-2 \mathrm{C}\left(\mathrm{ONO}_{3}\right)+2 \mathrm{NO}$

$-\mathrm{C}\left(\mathrm{NO}_{2}\right)+-\mathrm{C}\left(\mathrm{NO}_{2}\right) \rightarrow-\mathrm{C}_{2}\left(\mathrm{ONO}_{2}\right)+\mathrm{NO}$

$-\mathrm{C}_{2}\left(\mathrm{ONO}_{2}\right) \rightarrow 2-\mathrm{C}(\mathrm{O})+\mathrm{NO}$

The $\mathrm{NO}_{2}$ could be directly adsorbed/desorbed by functional group " $-\mathrm{C}^{*}$ " as Eq. (1), while the stability of adsorbed structure, $-\mathrm{C}(\mathrm{ONO})$, was not stable and tend to broken down and release one molecule of $\mathrm{NO}$ and form one $-\mathrm{C}(\mathrm{O})$ group (as shown in Eq. (2)). Additionally, the functional - $\mathrm{C}(\mathrm{O})$ could bind two $\mathrm{NO}_{2}$ and temporarily form two groups of $-2 \mathrm{C}\left(\mathrm{ONO}_{2}\right)$ (as shown in Eq. (3)). Furthermore, the $\mathrm{C}\left(\mathrm{ONO}_{2}\right)$ groups might temporarily react with extra $\mathrm{NO}_{2}$ molecule and form a more stable functional group, $-\mathrm{C}\left(\mathrm{ONO}_{3}\right)$ as shown in Eq. (4). On the other hand, the Eq. (5) indicates that two adjacent $-\mathrm{C}\left(\mathrm{NO}_{2}\right)$ groups could be combined and converted to a stable $-\mathrm{C}_{2}\left(\mathrm{ONO}_{2}\right)$, and one molecule of $\mathrm{NO}$ would escape from the AC surface. Eq. (6) reports that of $-\mathrm{C}_{2}\left(\mathrm{ONO}_{2}\right)$ could be decomposed and formed $-\mathrm{C}(\mathrm{O})$ and $\mathrm{NO}$, when the carbon is thermally regenerated.

Fig. 2(B) shows time variations of $\mathrm{NO}_{2}, \mathrm{NO}$ and $\mathrm{NO}_{\mathrm{x}}$ concentrations of the gases to and from the bed packed with the regenerated AC. At the start of adsorption, effluent gas had a NO concentration of $180 \mathrm{ppm}$ and in which the additional $130 \mathrm{ppm}$ was converted from the adsorbed $\mathrm{NO}_{2}$ according to Eqs. (1) and (2). However, during the initial $90 \mathrm{~min}$, there was less than $10 \mathrm{ppm} \mathrm{NO}_{2}$ emitted from the bed, representing over $90 \%$ removal efficiency (as shown in Fig. 3), and most $\mathrm{NO}_{\mathrm{x}}$ was in the form of NO. Afterwards, $\mathrm{NO}_{2}$ increased nearly exponentially and NO decreased nearly linearly with time. At the time of $360 \mathrm{~min}$, rates of $\mathrm{NO}_{2}$ increase, NO decrease as well as the influent and effluent $\mathrm{NO}_{\mathrm{x}}$ were nearly equal. After $480 \mathrm{~min}$, the bed lost its performance for $\mathrm{NO}_{2}$ removal.

\section{$\mathrm{NO}_{2}$ Adsorptive Removal Performances}

By the data shown in Figs. 2 and 3 show time variations of $\mathrm{NO}_{2}$ removal by the virgin and regenerated $\mathrm{AC}$. The removal is defined by subtracting the effluent $\mathrm{NO}_{2}$ concentration from the influent one and divided by the influent value. The Sshape profiles demonstrate that the adsorptive $\mathrm{NO}_{2}$ removal decreased from $100 \%$ slowly to around $80 \%$ during the beginning period which lasted about $50 \%$ of the breakthrough time for both adsorption operations. The phenomena are typical for mass transfer of pollutant(s) to the carbon surface with the fluid flowing through the carbon column. For the column with a packing height of $2.0 \mathrm{~cm}$ or $0.75 \mathrm{~g}$ of the virgin $\mathrm{AC}, 50 \%$ of the packed AC has a capacity of removing 80 $100 \%$ or around $90 \%$ of the influent $\mathrm{NO}_{2}$. For the adsorption test with the virgin $\mathrm{AC}$, it was estimated that during the initial $360 \mathrm{~min}$ (removal efficiency $>20 \%$ ) of the adsorption 


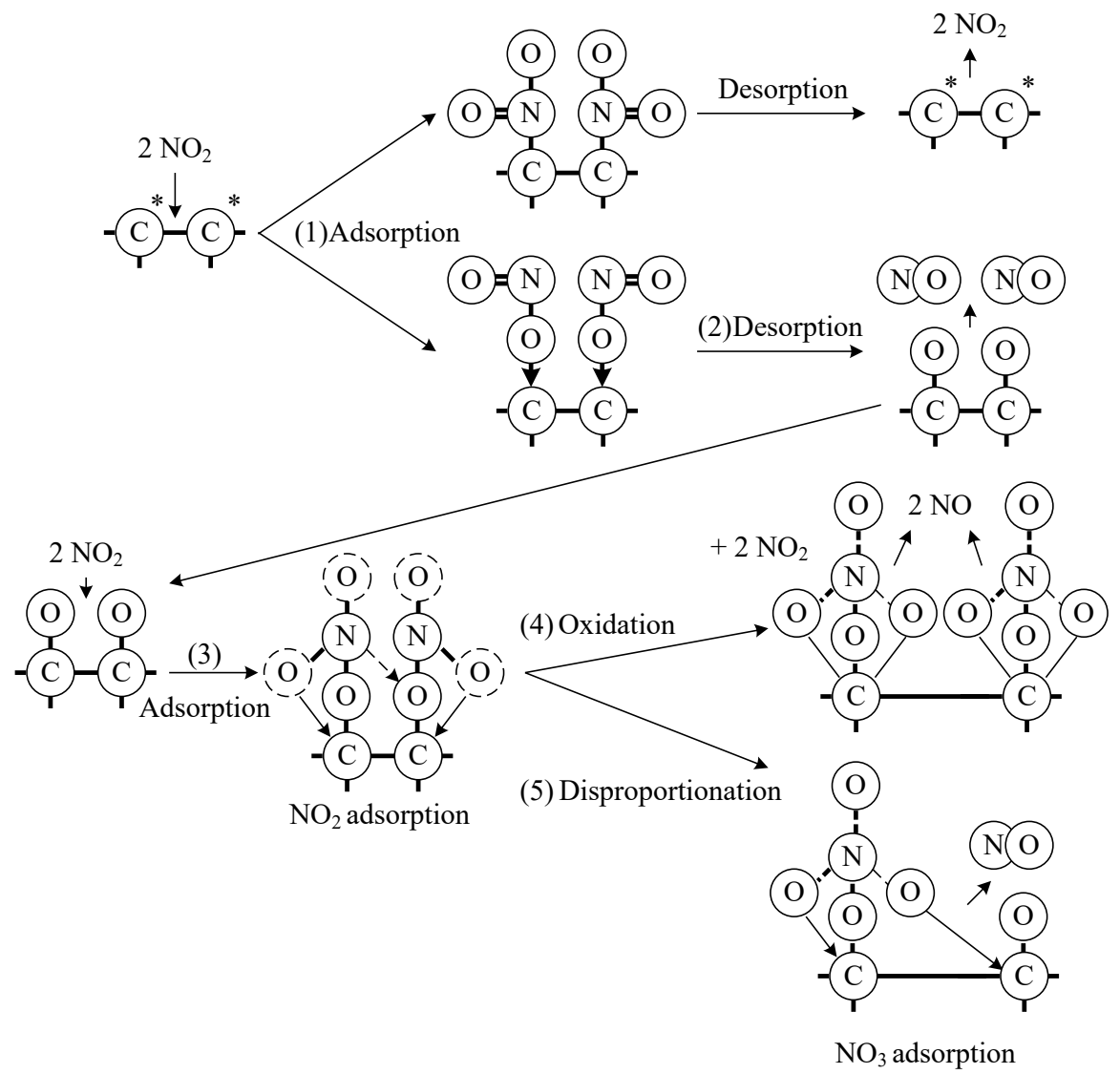

Fig. 4. Adsorption and desorption mechanism of $\mathrm{NO}_{2}$ by $\mathrm{AC}$ bed.

time, the total influent $\mathrm{NO}_{2}$ was $93.3 \mathrm{mg}\left(=0.6 \mathrm{~L} \mathrm{~min}^{-1} \times\right.$ $\left.360 \mathrm{~min} \times 220 \mathrm{ppm} \times 0.001 \mathrm{~m}^{3} \mathrm{~L}^{-1} \times 46\left(\mathrm{mg} \mathrm{m}^{-3}\right) / 24.5 \mathrm{ppm}\right)$. There were $90 \%$ of $\mathrm{NO}_{2}(84.0 \mathrm{mg})$ adsorbed. From the data, the adsorptive removal capacity of $\mathrm{NO}_{2}$ by the virgin $\mathrm{AC}$ was estimated to be $224 \mathrm{mg}$ g-AC ${ }^{-1}$. Table 2 shows that the superficial velocity for the gas flowing through the column cross-sectional area was $0.127 \mathrm{~m} \mathrm{~s}^{-1}$ and by this velocity, the length of mass-transfer zone for the removal of $80 \%$ of the influent $\mathrm{NO}_{2}$ could be estimated to be $0.5 \mathrm{~cm}$.

Similarly, for the regenerated $\mathrm{AC}$ with a packing height of $1.7 \mathrm{~cm}$, it was estimated that during the initial $240 \mathrm{~min}$ (removal efficiency $>20 \%$ ) of the adsorption time, the total influent $\mathrm{NO}_{2}$ was $59.5 \mathrm{mg}\left(=0.6 \mathrm{~L} \mathrm{~min}^{-1} \times 240 \mathrm{~min} \times 220 \mathrm{ppm}\right.$ $\left.\times 0.001 \mathrm{~m}^{3} \mathrm{~L}^{-1} \times 46\left(\mathrm{mg} \mathrm{m}^{-3}\right) / 24.5 \mathrm{ppm}\right)$. Fortunately, the $90 \%$ in average $(53.6 \mathrm{mg})$ could be still removed by regenerated $\mathrm{AC}$ bed in certain time ( $240 \mathrm{~min}$ ) period before breakthrough. The adsorptive removal capacity of $\mathrm{NO}_{2}$ by the regenerated $\mathrm{AC}$ was $155 \mathrm{mg}$ g-AC ${ }^{-1}$. The regenerated $\mathrm{AC}$ has a capacity of about $70 \%$ as compared with the virgin one. Bazan et al. (2016) used carbonaceous adsorbents obtained from the residue after supercritical extraction of marigold subjected to physical activation and used as nitrogen dioxide adsorbents. Dry air with $1,000 \mathrm{ppm}$ of $\mathrm{NO}_{2}$ was passed through a column packed with the adsorbents. Results showed that the most effective adsorbent in dry conditions had a $\mathrm{NO}_{2}$ sorption capacity of $29.2 \mathrm{mg} \mathrm{g}^{-1}$. The capacity was far less the that obtained by the present study.

Take the whole packed AC mass, Fig. 5 shows time variations of $\mathrm{NO}_{2}$ adsorptive removal capacity of both $\mathrm{AC}$. Calculate capacity by dividing the cumulative mass of removed $\mathrm{NO}_{2}$ by the total filled $\mathrm{AC}$ mass. The virgin $\mathrm{AC}$ had an equilibrium capacity of around $157 \mathrm{mg} \mathrm{NO}_{2} \mathrm{~g}^{-1} \mathrm{AC}$ with the adsorption time approaching $600 \mathrm{~min}$. The regenerated one had a saturation value of $113 \mathrm{mg} \mathrm{NO}_{2} \mathrm{~g}^{-1} \mathrm{AC}$ with time approaching $420 \mathrm{~min}$. As a comparison, the regenerated one had a capacity and saturation time of both $70 \%$ from the experimental data shown in Fig. 5.

Eqs. (2), 4, and (5) display that NO can be produced from

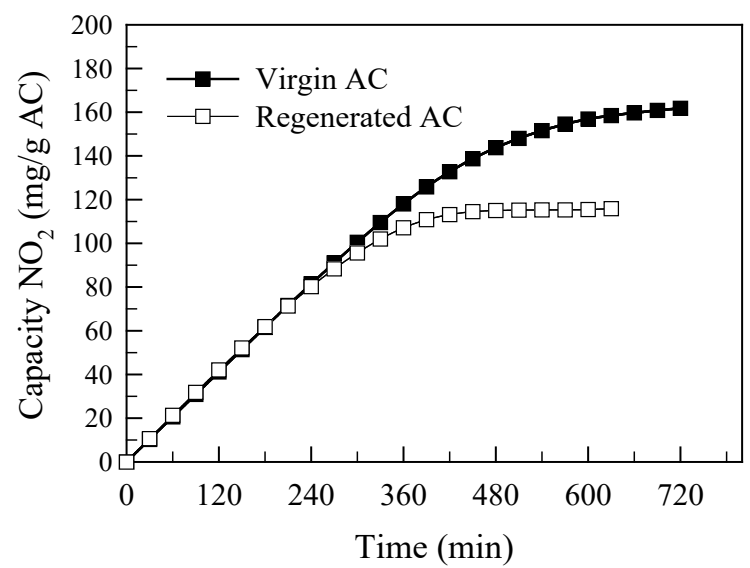

Fig. 5. Time variations of the adsorptive removal capacity of $\mathrm{NO}_{2}$ by the $\mathrm{AC}$. 


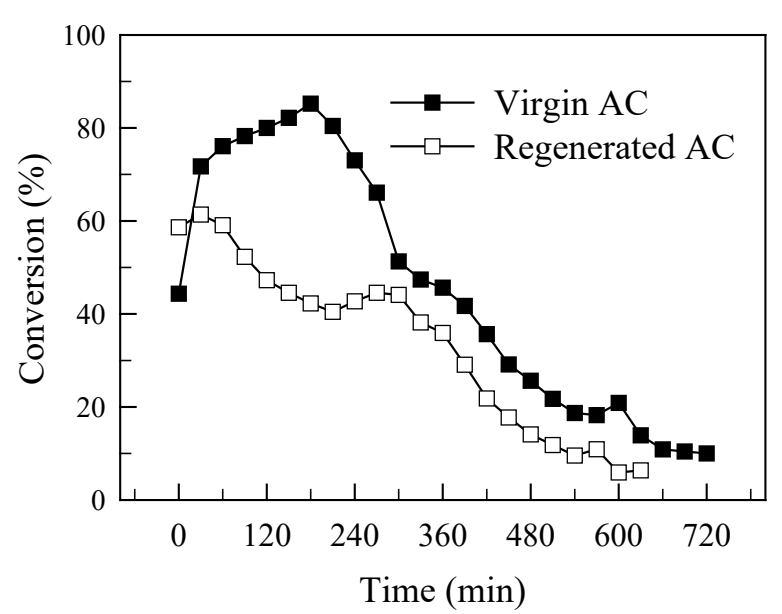

Fig. 6. Time variations of conversion of $\mathrm{NO}_{2}$ to $\mathrm{NO}$ by the AC.

the adsorptive removal of $\mathrm{NO}_{2}$ as illustrated in Fig. 2. Time variations of conversion of $\mathrm{NO}_{2}$ to $\mathrm{NO}$ by the $\mathrm{AC}$ were shown in Fig. 6. The conversion was calculated by dividing the NO increase (ppm) of the effluent gas by the influent $\mathrm{NO}_{2}$ concentration (220 and $230 \mathrm{ppm}$ for the test with virgin and regenerated $\mathrm{AC}$, respectively). At the start of operation by using the virgin $\mathrm{AC}$, the conversion was $44 \%$ and increased to a maximum of $85 \%$ in $180 \mathrm{~min}$ and decreased finally to about $10 \%$ at $720 \mathrm{~min}$. By the regenerated $\mathrm{AC}$, the conversion was $60 \%$ at the start and decreased with time to about $5 \%$ at $630 \mathrm{~min}$. By the virgin $\mathrm{AC}$, the new carbon had a greater ability to adsorb $\mathrm{NO}_{2}$ to form "-C(NO 2$)$ ", when only a part of them converted to NO and desorbed to the effluent gas. At around $180 \mathrm{~min}$, it could be postulated that reactions (2), (4) and (5) dominated with $\mathrm{NO}$ converted from the decomposition of $-\mathrm{C}\left(\mathrm{NO}_{2}\right)$ and $-\mathrm{C}_{2}\left(\mathrm{ONO}_{2}\right)$. After the time, there was no enough surface area available for effective adsorption of $\mathrm{NO}_{2}$ and its conversion to NO thus reduced. For the regenerated $\mathrm{AC}$, effective adsorption of $\mathrm{NO}_{2}$ and its conversion to $\mathrm{NO}$ occurred in the initial $60 \mathrm{~min}$. However, the AC could not convert the adsorbed $\mathrm{NO}_{2}$ to $-\mathrm{C}\left(\mathrm{NO}_{2}\right)$, while the conversion reduced gradually until the end of operation.

\section{Characteristics of $A C$}

The chemical regeneration method could only recover $70 \%$ of $\mathrm{NO}_{2}$ adsorptive removal capacity. This loss could attribute to changes in specific surface area, pore volume, and oxygen content in AC material before and after adsorption (as shown in Table 3 ). The specific surface areas of the virginunused and -saturated AC were 676 and 256 and $\mathrm{m}^{2} \mathrm{~g}^{-1}$, respectively. The $62 \%$ [ $=(676-256) / 676 \times 100 \%]$ reduction of surface area could be occupied by the oxidizing substances, such as $-\mathrm{C}(\mathrm{O}),-\mathrm{C}\left(\mathrm{ONO}_{2}\right)$ and $-\mathrm{C}_{2}\left(\mathrm{ONO}_{2}\right)$, produced by $\mathrm{NO}_{2}$ adsorption processes. After the washing regeneration process, the specific surface area of the regenerated AC was recovered to $551 \mathrm{~m}^{2} \mathrm{~g}^{-1}$ and reduced to $235 \mathrm{~m}^{2} \mathrm{~g}^{-1}$ after the $\mathrm{NO}_{2}$ saturated adsorption. The specific surface area differences between unused and saturated $\mathrm{AC}$ was $316 \mathrm{~m}^{2} \mathrm{~g}^{-1}$ (= 57\% of the initial value. The ratio of $316 / 420$ or $75 \%$ of the avail surface area of the virgin and the regenerated $\mathrm{AC}$ is near $70 \%$ which corresponds to the ratios of capacity and saturation time as discussed in the preceding paragraph. From the results, it could be postulated that around $57-62$ or $60 \%$ of the total surface area were available and responsible for processing raw and regenerative $\mathrm{AC}$.

The oxygen contents of the virgin AC increased from 3.79 to $5.09 \mathrm{wt} . \%$ after adsorption, and the increase was $1.30 \mathrm{wt} . \%$ which might be attributed by the adsorbed oxygen-containing species as cited in Eqs. (2)-(4). The regeneration reduced the oxygen contents from 5.09 to $3.12 \mathrm{wt} \%$, however, the regenerated $\mathrm{AC}$ did not restore its original performance due to pores and surface area volume reduction as shown in Table 3 . The oxygen content of the regenerated AC after adsorption increased to $6.21 \mathrm{wt} . \%$.

Table 3 also lists pore volume of the virgin and regenerated $\mathrm{AC}$ before and after adsorption. Pore volume of the virgin AC reduced from 0.326 to $0.124 \mathrm{~cm}^{3} \mathrm{~g}^{-1}$ after adsorption, and the decrease was $0.202 \mathrm{~cm}^{3} \mathrm{~g}^{-1}$. For the regenerated AC, The reduction before and after adsorption was $0.154 \mathrm{~cm}^{3} \mathrm{~g}^{-1}$, 0.262 and $0.108 \mathrm{~cm}^{3} \mathrm{~g}^{-1}$, respectively. The ratio of $0.154 / 0.202$ or $76 \%$ of the pore volume decrease is near $70 \%$ which corresponds to the ratios of capacity and saturation time as discussed in the proceeding section. Fig. 7 shows pore volume distributions of the virgin and regenerated AC. For the virgin $\mathrm{AC}$, most pores had sizes between 1.1 to $2.5 \mathrm{~nm}$ and the volume reduction occurred mainly in the same pore size range. The regenerated AC had similar pore size as the virgin one, however, the reduction in pore volume occurred mainly in the size range of $1.1-1.5 \mathrm{~nm}$.

\section{Regeneration Leachate}

Table 4 shows properties of aqueous solution leached from AC regeneration. Aqueous solution from the first leaching operation by alkaline water adjusted to $\mathrm{pH} 10$ turned to acidic with a $\mathrm{pH}$ of 2.36. The leachate from the second leaching operation by pure water was also acidic with a $\mathrm{pH}$ of 3.77. Nitrate was the only anion detected in both leachates. Gao et al. (2011) states that the adsorbed $\mathrm{NO}_{2}$ might converted into an adsorbed form of nitrate as $-\mathrm{C}_{2}\left(\mathrm{ONO}_{2}\right)$. Upon leaching, $-\mathrm{C}_{2}\left(\mathrm{ONO}_{2}\right)$ hydrolyzed to aqueous nitrate and the corresponding equation might be expressed as:

$$
2-\mathrm{C}_{2}\left(\mathrm{ONO}_{2}\right)+2 \mathrm{OH}^{-} \rightarrow 3-\mathrm{C}^{*}+-\mathrm{C}(\mathrm{O})+2 \mathrm{NO}_{3}^{-}+\mathrm{H}_{2} \mathrm{O}
$$

Table 3. BET surface area, pore volume, and oxygen content of AC.

\begin{tabular}{llll}
\hline Activated Carbon Columns & Oxygen content, wt. $\%$ & Surface area, $\mathrm{m}^{2} \mathrm{~g}^{-1}$ & Pore volume, $\mathrm{cm}^{3} \mathrm{~g}^{-1}$ \\
\hline Virgin & 3.79 & 676 & 0.326 \\
Virgin after adsorption & 5.09 & 256 & 0.124 \\
Regenerated & 3.12 & 551 & 0.262 \\
Regenerated after adsorption & 6.21 & 235 & 0.108 \\
\hline
\end{tabular}



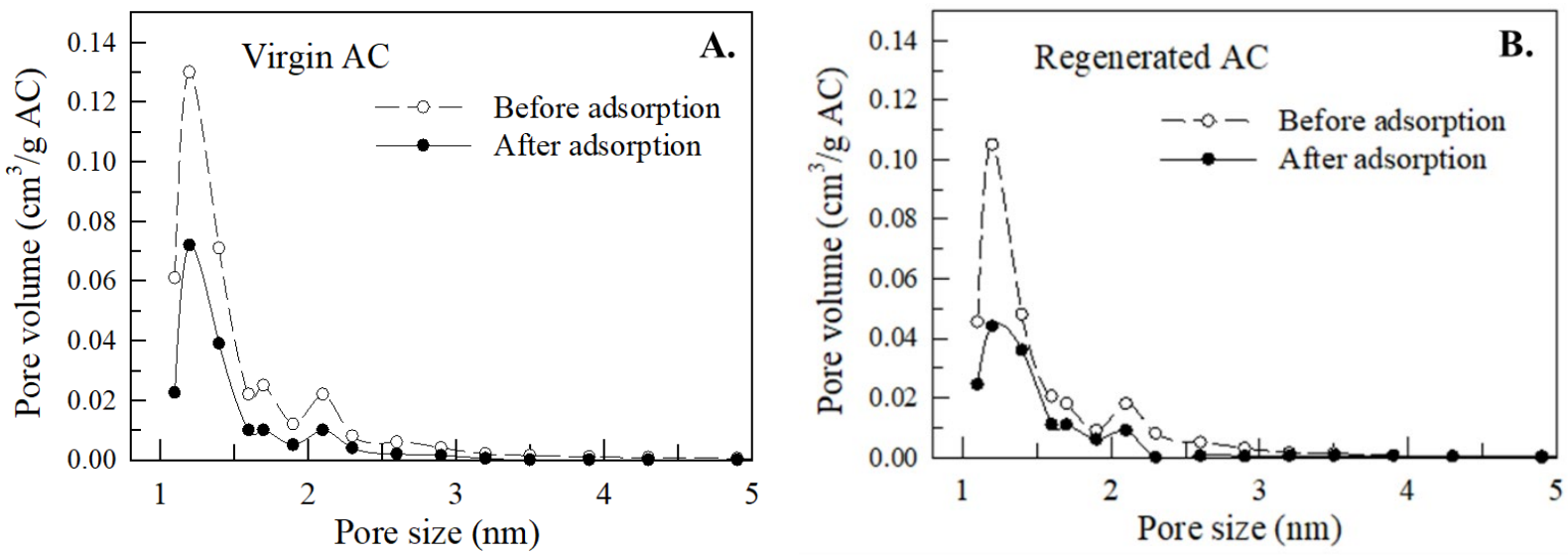

Fig. 7. Pore volume distributions of the (A) virgin $\mathrm{AC}$ and (B) regenerated $\mathrm{AC}$.

Table 4. Properties of aqueous solution leached from AC regeneration.

\begin{tabular}{lll}
\hline \multirow{2}{*}{ Liquid for regeneration } & \multicolumn{2}{c}{ Leached water from AC regeneration } \\
\cline { 2 - 3 } & $\mathrm{NO}_{3}{ }^{-}\left(\mathrm{mg} \mathrm{L}^{-1}\right)$ & $\mathrm{pH}$ \\
\hline Alkaline water & 624 & 2.36 \\
Pure water & 25.7 & 3.77 \\
\hline
\end{tabular}

$2-\mathrm{C}_{2}\left(\mathrm{ONO}_{2}\right)+\mathrm{H}_{2} \mathrm{O} \rightarrow 3-\mathrm{C}^{*}+-\mathrm{C}(\mathrm{O})+2 \mathrm{HNO}_{3}$

Eqs. (7) and (8) demonstrate that the adsorption site "-C*" could be regenerated by leaching the adsorbed AC by alkaline solution or water, and oxygen contents of the AC could be reduced.

\section{CONCLUSIONS}

In this study, passing the test air stream containing $230 \pm$ 10 ppm $\mathrm{NO}_{2}$ and $50 \mathrm{ppm}$ nitric oxide (NO) through an activated carbon-packed bed for the purpose of studying the adsorptive conversion behavior of $\mathrm{NO}_{2}$ by the activated carbon $(\mathrm{AC})$ at room temperature. The regenerated carbon was regenerated by washing with a water and caustic solution, and dried to carry out repeated adsorption tests. The following conclusions can be drawn:

1. At the beginning of adsorption, two nitrogen dioxide molecules combined with two adjacent $-\mathrm{C}^{*}$ (or -OC group) to from $-\mathrm{C}\left(\mathrm{NO}_{2}\right)$ or $-\mathrm{C}\left(\mathrm{ONO}_{2}\right)$, and release molecules of $\mathrm{NO}$ from the $\mathrm{AC}$ surface. The adjacent group of $-\mathrm{C}\left(\mathrm{NO}_{2}\right)$ could further form $-\mathrm{C}_{2}\left(\mathrm{ONO}_{2}\right)$ and enhance the stability of adsorbed $\mathrm{NO}_{2}$.

2. The net adsorptive conversion removal capacity of $\mathrm{NO}_{2}$ by the virgin $\mathrm{AC}$ and regenerated $\mathrm{AC}$ was 224 and 155 $\mathrm{mg} \mathrm{g}^{-1} \mathrm{AC}$, respectively, during the initial $50 \%$ of the breakthrough time. For the whole breakthrough time, the virgin $\mathrm{AC}$ had an equilibrium capacity of around 157 and $113 \mathrm{mg} \mathrm{NO}_{2} \mathrm{~g}^{-1} \mathrm{AC}$.

3. Regeneration restored around $70-75 \%$ of effective surface area, pore volume, and adsorptive conversion capacity of the virgin AC. Leached caustic solution obtained from the carbon regeneration contained only nitrate and the phenomena indicates the adsorbed $-\mathrm{C}_{2}\left(\mathrm{ONO}_{2}\right)$ hydrolyzed following the equation $2-\mathrm{C}_{2}\left(\mathrm{ONO}_{2}\right)+\mathrm{H}_{2} \mathrm{O}$ $\rightarrow 3-\mathrm{C}^{*}+-\mathrm{C}(\mathrm{O})+2 \mathrm{HNO}_{3}$.

The positive results of $\mathrm{NO}_{2}$ removal by $\mathrm{AC}$ column found in the current study promote the development of the realscale equipment and need to confirm its durability. The operation and phenomenon would be significantly different in a scale-up progress for a more practical use. The real-scale equipment could include twin beds, one in operation and the other in regeneration. A regeneration process will include (1) caustic desorption of the adsorbed $\mathrm{NO}_{2}$ and $\mathrm{NO}_{3}$, (2) water rinsing of the regenerated carbon, and (3) drying of the rinsed carbon.

\section{NOMENCLATURES}

$-\mathrm{C}^{*}$ : active site on the carbon surface.

$-\mathrm{C}(\mathrm{O})$ : oxygenated carbon surface.

\section{ACKNOWLEDGMENTS}

This is to appreciate the co-author participants for their professional consultation, technical support, and all other efforts.

\section{REFERENCES}

Bazan, A., Nowicki, P. and Pietrzak, R. (2016). Removal of $\mathrm{NO}_{2}$ by carbonaceous adsorbents obtained from residue after supercritical extraction of marigold. Adsorption 22: 465-471.

Chen, L., Lin, J.W. and Yang, C.L. (2002). Absorption of $\mathrm{NO}_{2}$ in a packed tower with $\mathrm{Na}_{2} \mathrm{SO}_{3}$ aqueous solution. Environ. Prog. Sustainable Energy 21: 225-230.

Chen, L., Lin, K.F. and Yang, C.L. (2011). Pilot study of absorption of $\mathrm{NO}_{2}$ with $\mathrm{Na}_{2} \mathrm{~S}$ aqueous solutions. Environ. Prog. Sustainable Energy 30: 632-639. 
Chen, Y., Wang, M., Du, X., Ran, J., Li, Z. and Tang, D. (2018). High resistance to $\mathrm{Na}$ poisoning of the $\mathrm{V}_{2} \mathrm{O}_{5}-\mathrm{Ce}$ $\left(\mathrm{SO}_{4}\right)_{2} / \mathrm{TiO}_{2}$ catalyst for the NO SCR reaction. Aerosol Air Qual. Res. 18: 2948-2955.

Curtin, T. (2005). Selective catalytic reduction of $\mathrm{NO}_{\mathrm{x}}$. In Environmental catalysis, Grassian, V.H. (Ed.), CRC Press, Boca Raton, pp. 197-210.

Du, W., Zhang, Y., Chen, Y., Xu, L., Chen, J., Deng, J., Hong, Y. and Xiao, H. (2017). Chemical characterization and source apportionment of $\mathrm{PM}_{2.5}$ during spring and winter in the Yangtze River Delta, China. Aerosol Air Qual. Res. 17: 2165-2180.

Fang, C., Zhang, Z., Jin, M., Zou, P. and Wang, J. (2017). Pollution characteristics of $\mathrm{PM}_{2.5}$ Aerosol during haze periods in Changchun, China. Aerosol Air Qual. Res. 17: 888-895.

Gao, X. Guo, R.T. Ding, H.L. Luo, Z.Y. and Cen, K.F. (2009). Absorption of $\mathrm{NO}_{2}$ into $\mathrm{Na}_{2} \mathrm{~S}$ solution in a stirred tank reactor. J. Zhejiang Univ. Sci. A 10: 434-438.

Gao, X., Liu, S., Zhang, Y., Luo, Z., Ni, M. and Cen, K. (2011). Adsorption and reduction of $\mathrm{NO}_{2}$ over activated carbon at low temperature. Fuel Process. Technol. 92: $139-146$.

Görgülü, A., Koç, Y., Yağlı, H. and Koc, A. (2018). Adsorption of nitrogen dioxide $\left(\mathrm{NO}_{2}\right)$ for different gas concentrations, temperatures and relative humidities by using activated carbon filter: An experimental study. Int. J. Adv. Eng. Res. Sci. 5: 2349-2456.

Guo, R.T., Pan, W.G., Zhang, X.B., Ren, J.X., Jin, Q. and $\mathrm{Xu}$, H.J. (2012). Absorption of $\mathrm{NO}_{2}$ into aqueous $\left(\mathrm{NH}_{4}\right)_{2} \mathrm{SO}_{3}$ solution in a stirred tank reactor. Environ. Prog. Sustainable Energy 32: 465-469.

Huang, Y., Cao, J.J, Kang, F., You, S.J, Chang, C.W. and Wang, Y.F. (2017). High selectivity of visible-lightdriven La-doped $\mathrm{TiO}_{2}$ photocatalysts for $\mathrm{NO}$ removal. Aerosol Air Qual. Res. 17: 2555-2565.

Jiang, N., Guo, Y., Wang, Q., Kang, P., Zhang, R. and Tang, X. (2017). Chemical composition characteristics of $\mathrm{PM}_{2.5}$ in three cities in Henan, central China. Aerosol Air Qual. Res. 17: 2367-2380.

Liu, H.B., Zhang, Z.X., Li, Q., Chen, T.H., Zhang, C.G., Chen, D., Zhu, C.Z. and Jiang, Y. (2017). Novel methods for preparing controllable nanoporous $\alpha-\mathrm{Fe} 2 \mathrm{O}_{3}$ and its reactivity to SCR de-NO $\mathrm{NO}_{\mathrm{x}}$ Aerosol Air Qual. Res. 17: 1898-1908.

Persinger, R.L., Poynter, M.G., Ckless, K. and JanssenHeininger, Y.M. (2002). Molecular mechanisms of nitrogen dioxide induced epithelial injury in the lung. Mol. Cell. Biochem. 234-235: 71-80.

Shen, C.H. and Rochelle, G.T. (1998). Nitrogen dioxide absorption and sulfite oxidation in aqueous sulfite. Environ. Sci. Technol. 32: 1994-2003.

Shirahama, N., Moon, S.H., Choi, K.H., Enjoji, T., Kawano, S., Korai, Y., Tanoura, M. and Mochida, I. (2002). Mechanistic study on adsorption and reduction of $\mathrm{NO}_{2}$ over activated carbon fibers. Carbon 40: 2605-2611.

U.S. Environmental Protection Agency (U.S. EPA) (1987). Nitrogen dioxide CASRN 10102-44-0. Chemical Assessment Summary, Integrated Risk Information System (IRIS), National Center for Environmental Assessment.

Wang, Y., Cheng, K., Tian, H.Z., Yi, P. and Xue, Z.G. (2018). Analysis of reduction potential of primary air pollutant emissions from coking industry in China. Aerosol Air Qual. Res. 18: 533-541.

Wu, C.Y. and Chou, M.S. (2014). Reduction of nitrogen dioxide from etching vent gases by scrubbing with caustic sodium sulfide solution. J. Chem. Technol. Biotechnol. 89: 1850-1858.

Xu, J.Y., Jiang, H., Zhao, H.R. and Stephens, B. (2017). Mobile monitoring of personal $\mathrm{NO}_{\mathrm{x}}$ exposures during scripted daily activities in Chicago, IL. Aerosol Air Qual. Res. 17: 1999-2009.

Zhang, W.J., Bagreev, A. and Rasouli, F. (2008). Reaction of $\mathrm{NO}_{2}$ with activated carbon at ambient temperature. Ind. Eng. Chem. Res. 47: 4358-4362.

Zhang, X., Kang, J., Chen, H., Yao, M. and Wang, J. (2017). $\mathrm{PM}_{2.5}$ meets blood: In vivo damages and immune defense. Aerosol Air Qual. Res. 18: 456-470.

Received for review, September 5, 2019 Revised, October 16, 2019 Accepted, October 19, 2019 